\title{
Need Assement For Graduate Users Through Tracer Study on Lecturer Groups of Beauty Education Study Program Universitas Negeri Medan
}

\author{
S.Wahidah $^{1 *}$, D.Afanty Lubis ${ }^{1}$, L.Pangaribuan ${ }^{1}$, H.Hanim ${ }^{1}$ \\ \{*sitiwahidahrias@gmail.com\} \\ Universitas Negeri Medan, Medan, Indonesia ${ }^{2}$
}

\begin{abstract}
The results of the tracer study on curriculum implementation carried out in 2011 obtained graduate competency results not link and match with stakeholders 'needs and graduates' academic achievements (very high achievement index, but not in accordance with performance in the field). The purpose of this study was to develop the alumni of cosmetology education website. The population of this study were all alumni who were netted through the website and filled out questionnaires that had been developed previously, using the snowball method. This type of research is a Development research, which is developing the Makeup Cosmetology Alumni website, which starts from website product development, then is validated on the expert team, then individual trials and field trials are carried out. The instrument used is a questionnaire that is to capture alumni data, the presence of alumni, work, suitability of alumni works with competence, suitability of the curriculum with work, long working income, then the data is descriptive, to draw conclusions. The results of this study are the competence of graduates who still do not meet the criteria for the required competencies. Stakeholders where alumni work have not adjusted their graduates' competencies, there is still low information in the community in mastering competencies, in-come is not in accordance with alumni competencies. The conclusion of the above is to gather the existence of Makeup Arrangements alumni, the Cosmetology Study Alumni Program community is formed through a tracer study website, so that there is a forum for alumni and keep monitoring the presence of the Alumni.
\end{abstract}

Keywords: Tracer study, cosmetology education.

\section{Introduction}

Government policy through the decision of the Directorate of Higher Education, which states that universities must be able to prepare their graduates to compete in a competitive labor market or an imbalance between demand and supply, and the quality of human resources produced in an effort to explore information related to the transition from lecturing to the world of work while tracking alumni performance, a study called the tracer study was conducted.

In the ILO's presentation (2011) explained that tracer study has the following meanings: Tracer studies of take a retrospective look at the evolution of the situation of a sample of children already provided with or exposed to a specific intervention. It is an inquiry approach at a single point in time that generates data on already achieved impact. From this opinion, it is 
explained that tracer study is a method for tracing information on a sample that has been given a particular intervention which in time brings about the desired impact.

The KKNI curriculum is a curriculum that is oriented towards quality improvement which includes attitude, skills and knowledge. The implementation of the new Higher Education Paradigm is a curriculum change from content-based to competence-based with the demands of changing times and labor market signals. This situation leads to the consequences of curriculum fees that are demanded by the stake-holder parties. This guideline must be followed up by reviewing and identifying the latest market needs that have a vision in the future so that out-put (graduates) receive an appropriate award on the job. Many efforts can be made in identifying market needs as a foundation in the curriculum content, one of which is by searching graduates to see the initial conditions. To trace the profile of market needs, one method can be done by tracking graduates to alumni.

Based on the alumni data base at the Cosmetology Education Study Program level only provides information about the graduate address data obtained at the time of completion of the study (graduation). Data collection and traceability of alumni has not been maximized so that the presence of alumni after completing the study cannot be tracked. Data on temporary alumni is only obtained through personal information that has not been well documented. The choice of graduate tracing that is in accordance with the needs of the labor market is best done to obtain information on the absorption capacity of graduates towards the labor market. The search is carried out to be able to improve the competence of graduates in competing in the world of work.

To see how far the Cosmetology Education Study Program graduates can benefit the community, in accordance with their main competencies, it is necessary to conduct a tracer study. This tracking study is important because after graduates enter the workforce, it is very difficult to find information about the existence of graduates. The number of graduates absorbed into the world of work is also difficult to know. The suitability of the field of work of graduates cannot be known, as well as the ability of graduates from the point of view of the stakeholders. At this point the search and data collection of alumni is important to do. Tracer study on the one hand is undoubtedly to be done as one of the study program accreditation databases, and becomes increasingly important in its role because it can provide various information to evaluate the relevance of higher education in this case Cosmetology Education Study Program with the world of work. Feedback from graduates and graduate users can be used as material for evaluation and improvement of the curriculum.

The tracer study process is expected to provide useful input for lecturers and administrators to improve performance, as well as information for the public in monitoring the world of higher education. From the search of alumni related data, it is known that during this time the Makeup Management Study Program has never conducted a tracer study structured with a methodology that can be accounted for academically. Tracer studies that have been conducted in preparation for the submission of accreditation / reaccreditation. As a result, the implementation tends to simply prepare data to meet the administrative requirements for accreditation. So, whatever the results, the implementation is not sustainable and difficult to aggregate at a higher level to improve the implementation of the study program. This research focuses on the issue of external success through alumni tracking of the Cosmetology Education Study Program. To answer the main problem, in this study a problem was formulated which was described as follows; 1) How to map the realm of work for Makeup Cosmetology alumni in a career? 2) What is the relevance of the competence of alumni to the needs and demands of the job? 3) What are the supporting factors and constraints of alumni in 
getting a job? 4) What additional competencies should alumni have to be able to compete in the world of work?

Tracer study is a study whose main purpose is to obtain information about graduates who have worked and have not worked. In addition, tracer study aims to find out the results of education in the form of mastery and acquisition of graduate competencies that are applied in the world of work and the transition from the world of higher education to business and industry. Through this tracer study, education providers can find out how the implementation and quality of program services through the assessment of alumni. Through this, education providers are able to improve and improve the quality of their services.

Institutionally, in addition to obtaining important information in the form of alumni feedback as evaluation material to find out the relevance of higher education to employment, educational institutions are also billed by stakeholders about the real work of educating the nation's generation in the form of giving birth to academically qualified and elegant personalities. To carry out these noble ideals, educational institutions are required to continue to reorganize themselves and improve the quality of education services to the public. One of them is through the assessment of the study program performance by the National Higher Education Accreditation Board (BAN PT) and the preparation of the Self Evaluation report as the basis for organizational consolidation and the development of academic activity programs. One of the items of self-evaluation and content of accreditation forms is about the existence of graduates after leaving college. Tracer Study is a study conducted on college graduates related to the transition of higher education to the world of work. The target of the study are college graduates who are already working in an agency or entrepreneur or graduates who have not worked [7]. Tracer Study also provides valuable information from evaluating the results of education and training in certain agencies, thus tracer studies can provide a decision to plan future educational activities [8].

Tracer study of alumni is an empirical study that is expected to provide information to evaluate the results of education. This information is used for further development in ensuring the quality of education. With this tracer study activity, it is expected that will get information on indications of lack of implementation of study programs and provide the basics of future planning. For that information the success of professionalism (career, status, income) of alumni is needed. Similarly, information on relevant knowledge and expertise (the relationship between knowledge and expertise with work needs, scope of work, professional position).

Graduates search is an empirical research that can produce valuable information in evaluating an education program. Study information can be used as an effort to guarantee quality for the institution as a whole, in the sense that the institution continues to improve the program in accordance with input from the results of the graduates' search studies [2]. The relevance of graduate search studies on policy making in the field of curriculum and program development has long been known [3]. The study of graduates' searches plays a role in evaluating the curriculum of a learning program, showing the strengths and weaknesses of the program so as to produce fundamental improvement suggestions. The study can be the basis for seeing the relevance and effectiveness of the curriculum being taught in accordance with the needs of the job market, and how well the applicable curriculum can prepare alumni to deal with the demands of change in the work environment, as the study has been done by [4].

Because alumni have more independent ties with learning institutions, alumni have a more objective perception and perspective in evaluating the learning programs they have taken [5]. Thus, the opinion of alumni is very valuable information for the development of an institution. [6] proposed a new approach so that graduates' search studies could be used as a basis for program planning and future activities. In the study, in addition to information on the 
relevance of knowledge and skills acquired by graduates with needs in the workplace, professional success of graduates such as career, employment status, and income is traced. In addition, the job satisfaction of graduates is also an important indicator of the success of a program, as well as the study conducted by [9].

\section{Methodology}

Tracer studies for graduates of the Cosmetology Education Study Program are carried out through surveys involving graduates and supervisors as sources of data. Given the spread of graduates covering almost all of North Sumatra, the distribution of questionnaires used in tracer studies is carried out via e-mail and correspondence with respondents through the Web Site. Through the website developed questionnaires are more effective and the return of questionnaires from both sources of information can be monitored properly.

The method used in this study is descriptive to obtain an overview of the Makeup Cosmetology graduates. To obtain research data, a survey method is used using a questionnaire as a data collection tool. Furthermore, this study used a cross sectional study with a time range of one shot with the type of cross-section data, namely data collected at the time of a selected sample. Respondents study tracing of Makeup Cosmetology alumni. This study uses quantitative methods. For quantitative methods, a survey was conducted on all Cosmetology Education graduates who graduated in 2011-2017 through a questionnaire that was netted through the website. The step of developing an application for the web is done using software development methods with the step of developing a Waterfall model application. The application built is expected to be able to fulfill the following matters: a) Revision of bio data (previous bio data has been taken from the data while being a student, then given revision facilities if there is a change in data), b) Fill out the questionnaire in the application according to each login, c) Questionnaires in the form of: main job data or entrepreneurial activities, work, positive and negative comments about work / business, the contribution of the study program in the current job, the competence of the alumni, the reason for taking the field of work/business, the most important aspects of following job selection process or starting a makeup business. In general, the implementation of this tracer study is carried out in three stages, as shown in Figure 1 below shows the details of the tracer activities shown in the flow chart below. Tracer studies for graduates of the Cosmetology Education Study Program are carried out through surveys involving graduates and supervisors as sources of data. Given the spread of graduates covering almost all of North Sumatra, the distribution of questionnaires used in tracer studies is carried out via e-mail and correspondence with respondents through the Web Site. Through the website developed questionnaires are more effective and the return of questionnaires from both sources of information can be monitored properly.

The method used in this study is descriptive to obtain an overview of the Makeup Cosmetology graduates. To obtain research data, a survey method is used using a questionnaire as a data collection tool. Furthermore, this study used a cross sectional study with a time range of one shot with the type of cross-section data, namely data collected at the time of a selected sample. Respondents study tracing of Makeup Cosmetology alumni. This study uses quantitative methods. For quantitative methods, a survey was conducted on all Cosmetology Education graduates who graduated in 2011-2017 through a questionnaire that was netted through the website. The step of developing an application for the web is done 
using software development methods with the step of developing a Waterfall model application. The application built is expected to be able to fulfill the following matters: a) Revision of bio data (previous bio data has been taken from the data while being a student, then given revision facilities if there is a change in data), b) Fill out the questionnaire in the application according to each login, c) Questionnaires in the form of: main job data or entrepreneurial activities, work, positive and negative comments about work / business, the contribution of the study program in the current job, the competence of the alumni, the reason for taking the field of work/business, the most important aspects of following job selection process or starting a makeup business. In general, the implementation of this tracer study is carried out in three stages, as shown in Figure 1 below shows the details of the tracer activities shown in the flow chart below.

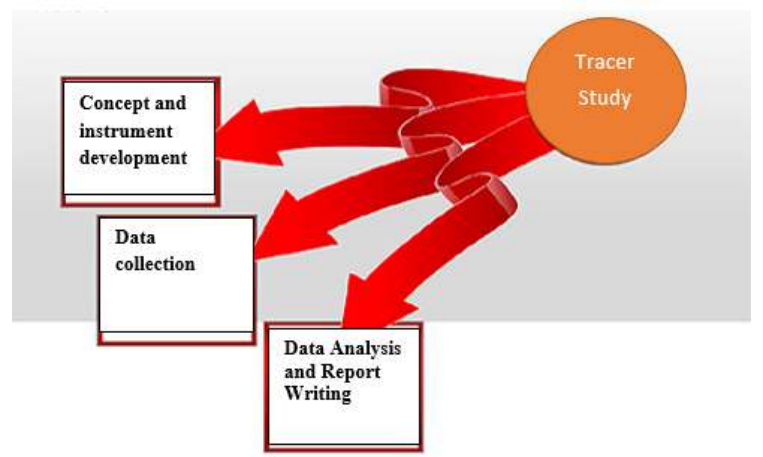

Fig.1. Flow Chart of Tracer Study

The web-based tracer study system by utilizing information technology is used as part of the implementation of this Tracer Study, it is hoped that it will be more interesting and easier for both data collection and analysis. In the System, there needs to be features especially related to respondents, graduate years, current jobs, the amount of salary and the meaning of makeup knowledge with current work.

\section{Result and Discussion}

Based on the R \& D procedure proposed by [10], the results achieved in the design of the tracer study program are as follows;

(1) Main page

The main page of the Makeup Tracer Study Education Study Program is the Home page. When accessing this website for the first time, the page that will appear is the Home page. This page contains a welcome slideshow on the Cosmetology Education study tracer and below the text is a button that directs to the tracer page. At the top of the display there is a logo on the left and navigation which consists of home, tracer, and about on the right side.

\section{(2) Tracer page}

The tracer page is the user's page for selecting the type of login user. There are three types of users in the Tracer Study Tracer Study of the Cosmetology Education Study Program, namely as alumni. On this page there is an explanation of the picture, the user types, and the login button for each user. On the tracer page, if the Tracer Study Program's Cosmetology 
Study Program website user, presses the alumni login button, the user chooses to be an alumnus of the Cosmetology Education Study Program. After the user presses the alumni button, the alumni login page will appear containing the login form for the alumni. This page consists of a username box that uses the Student Identification Number as the username, and a password entry box to enter the alumni user page. After successfully entering the alumni page if the alumni have not filled in their personal data, the alumni profile form will appear. In the alumni profile form, there is a box of names, gender, address, telephone / mobile number, email, class, year of graduation, work.

The questionnaire form will appear immediately after the alumni has logged in after filling in the personal data before or after the alumni has filled in their personal data. The questionnaire form is in the form of options ranging from 1 to 5. The type of data input type is in the HTML called the radio button. Using the radio button, you can only choose one answer for each problem. After the alumni answers all the questionnaires and presses the save button, the page will move to the page containing the text thank you for filling in the tracer study questionnaire. This page indicates that all data has been filled.

\subsection{Profile of Graduates of Cosmetology Education}

The graduate profile of the Cosmetology Education Study Program has a distinctive feature that distinguishes it from the profile of other skills education graduates. The profile is basically developed by each study program before the program is offered, even before developing the curriculum. Thus, before the opening of the program, the study program already has an overview of the graduate profile. In early 2016, the KKNI curriculum began to resonate again in the world of Higher Education in Indonesia. At the Higher Education level, Core Curriculum, the competency approach is officially applied. The core curriculum that previously applied nationally is not applied anymore because each curriculum is developed by each study program.

Competence can be defined in various ways as a set of smart actions, full of responsibilities that a person has as a condition to be considered capable by the community in carrying out tasks in a particular field of work. Based on this definition competence can be known for various fields, such as teacher competency, competence as medical personnel, agricultural extension workers, accountants, architects and so on. A person is considered competent in a particular field if he is able to show intelligent actions that are full of responsibility in the field, so he gets the trust of the community. Therefore, whether a person is competent or not in a particular job can be known through the opinions of the people served and of course the employer.

Smart and responsible action, which is a very complex decision-making action, based on various abilities, which in the Minister of National Education Decree No. 045 / U / 2002 referred to as the element of competence, which consists of: (1) foundation of personality, (2) mastery knowledge and skills, (3) ability to work, (4) attitude and behavior in working according to skill level based on knowledge and skills mastered, and (5) understanding the rules of community life in accordance with the choice of expertise in work.

The curriculum KKNI requires each graduate to master a set of competencies that have been developed before the curriculum is established. These competency devices are used as exit requirements or external requirements. That is, a student is declared a graduate of the program, if he has mastered the required competencies. Competency tools are developed by referring to the assumptions of the program's foundation, vision and mission of the Cosmetology Education Study Program, and the tasks/characteristics/demands of employment 
presented by graduates. By looking at the profile of these graduates, prospective students can determine which competencies match their abilities and expectations.

Previous Study Tracer Results a graduate tracer study was carried out by the Cosmetology Education Study Program Tracer Study Team in 2010. The study conducted by this Team is the initial stage of searching for a new Makeup Cosmetology Study Program Applicant. The results of the 2010 tracer study have not fully described the graduate profile. However, the number of questionnaires returned to the Tracer Study Team was 4 questionnaires (less representative). The four graduates have worked on the status and they claim to work in accordance with their expertise. Tracer studies graduates of the Cosmetology Education Study Program for 36 graduates from 259 graduates (graduates until 2009). The results of the study are as follows [11].

(1) Graduates who are respondents are 36 respondents, consisting of $34(93.3 \%)$ and 2 people (6.7\%). 2. Reasons for studying in Cosmetology Education because of the affordable costs $(94.4 \%)$, State Universities $(69.4 \%)$, adequate academic services $(16.7 \%)$, and according to job needs $(16.7 \%)$.

(2) Based on the experience of respondents during college, most respondents consider it to work well with aspects of knowledge, skills and attitudes.

(3) In the aspect of competence, most respondents consider having increased competency after graduating from the Cosmetology Education Study Program, but their ability to write and speak foreign languages has not increased according to their expectations.

(4) Most respondents were satisfied with the academic and administrative services provided by the Cosmetology Education Study Program, this case settlement service was still the last rank in the level of administrative service satisfaction.

(5) In the aspect of competitiveness, Makeup Cosmetology graduates have qualities that are not inferior to other tertiary graduates.

(6) Communication between Makeup Cosmetology alumni is still low due to ineffectiveness in the area.

From tracer study searches conducted from June to the end of October 2011 (four months) netted 30 Cosmetology Education alumni. After graduating from the student, the waiting period to get the first job is as shown in graph 1 below, stating that the highest percentage of 17 alumni $(60.00 \%)$ stated that they have waited a long time to get a job for more than 1 year. The waiting time between 6-12 months is $32.22 \%$ (9 people) and only $7.78 \%$ (4 people) are the waiting time to get a job less than 6 months.

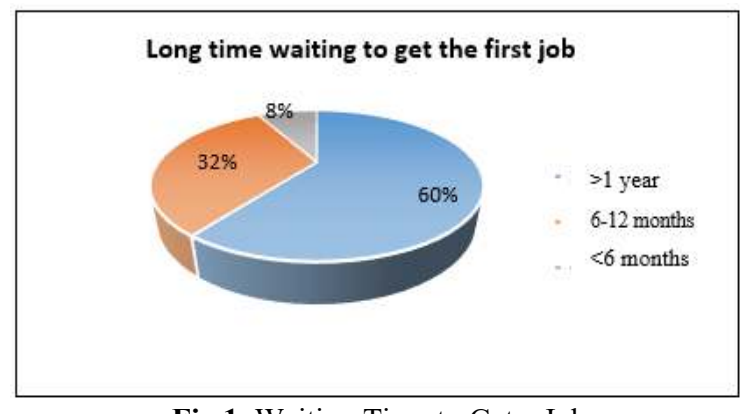

Fig.1. Waiting Time to Get a Job

In obtaining a job before graduation, the alumni stated that only 6 people $(20 \%)$ who had worked before graduating were part-time jobs only as a home decorator who did not open a 
salon, but could be called to make graduations, marriages and others, and the remaining $80 \%$ (24 people) said they had never worked.

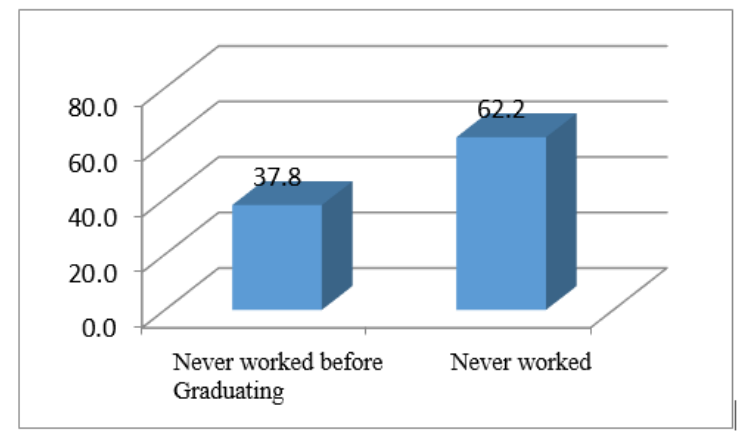

Fig.2. Who has worked before graduating

In the question "What is your current job in accordance with the field of science that you have?" Around (73.3\%) said that the work they got was in accordance with the field of knowledge they had, namely as honorary teachers at Vocational High Schools, opening their own businesses in accordance with their fields, namely opening salons and becoming bridal grooms, and only (26.7) and said their work was not in accordance with the knowledge they gained, namely credit sellers, working at a private bank and in the company as a secretary.

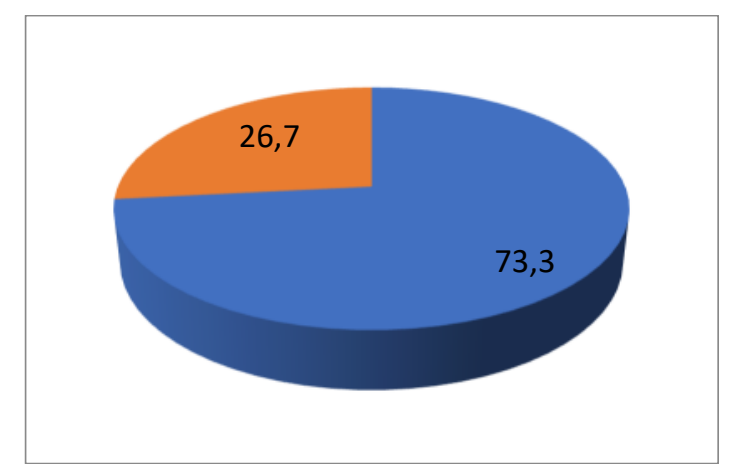

Fig.3. Jobs that are in accordance with the field of science owned

In figure 4 . It is unfortunate that there are no $0 \%$ of alumni participating in the alumni organization activities, this is likely to occur because the alumni organization in the Cosmetology Education Study Program has not been active and running properly, this has become a big whip for the Cosmetology Education Study Program immediately activating the organization that is actually an Alumni bond that has existed since 2013, but the reality in the field has not played a role to advance the Cosmetology Education Study Program. 


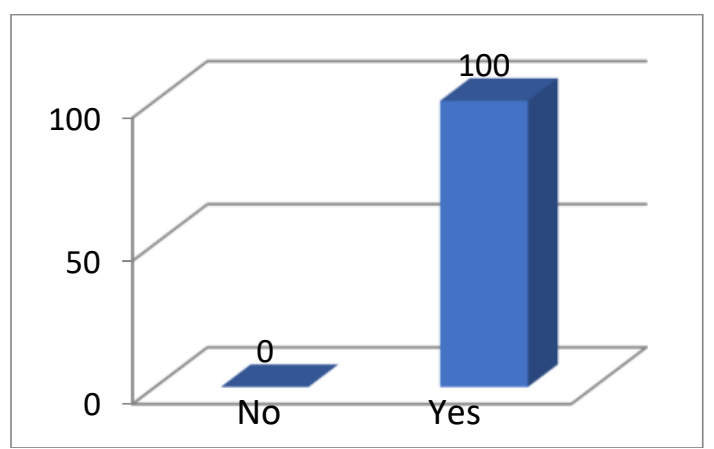

Fig.4. Alumni who follow the organization

The next question is how to participate when there are alumni organization activities? Considering that the alumni organization has not been active and is running well, all alumni answered that they were not active. Because the activities of the alumni organization have not been active so that all alumni (100\%) state they are not active in the organization as shown in figure 5 below.

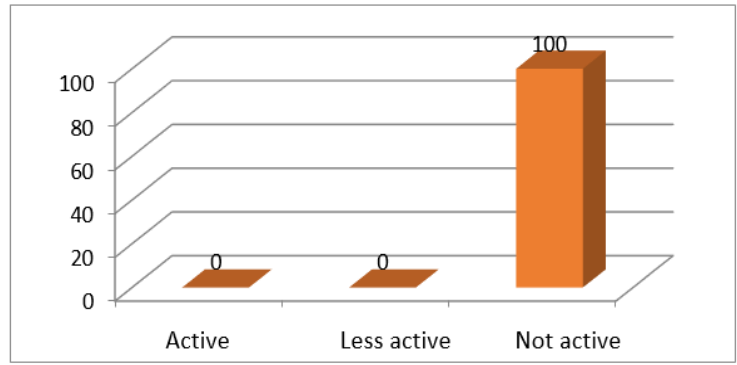

Fig.5. Alumni participation in Alumni organizations

Next is the question whether there is a function of the alumni organization that you follow in fostering graduates? Because the existence of the Alumni organization is not yet active, so the answers of $100 \%$ respondents stated that they have not functioned in their duties to foster alumni, which should be the activities of alumni organizations to foster alumni to be efficient in the labor market.

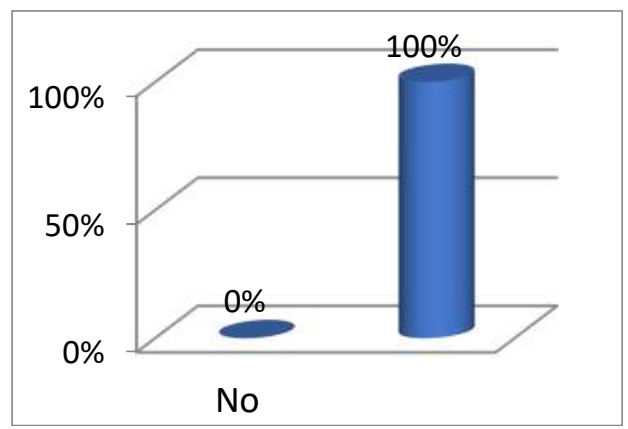

Fig.6. Function of alumni organization in fostering graduates 
In figure 7. It is seen that alumni who are always looking for information in getting jobs have $16.6 \%$ alumni who stated that they are actively seeking job information, while $56.6 \%$ are less active, and $26.6 \%$ say they are not active.

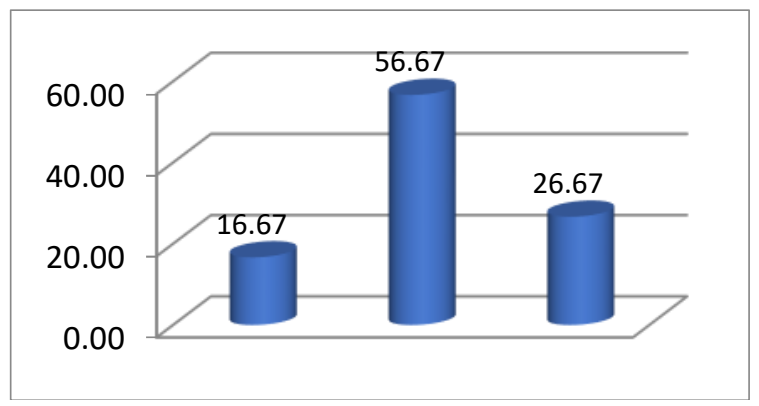

Fig.7. Finding job information gets a job

Regarding the alumni's opinion on the job market information source activities, such as the government, entrepreneurs, the Government Industry and Private Industry for the guidance of graduates, as shown in figure 8 below, 55\% of alumni said they were inactive and $33 \%$ uncertain. Those who play an active role in the job market information activities are only $0 \%$ and $13 \%$ less active. This is indicated that alumni do not feel that the job market can help them to find work, so they only seek work through friends or family.

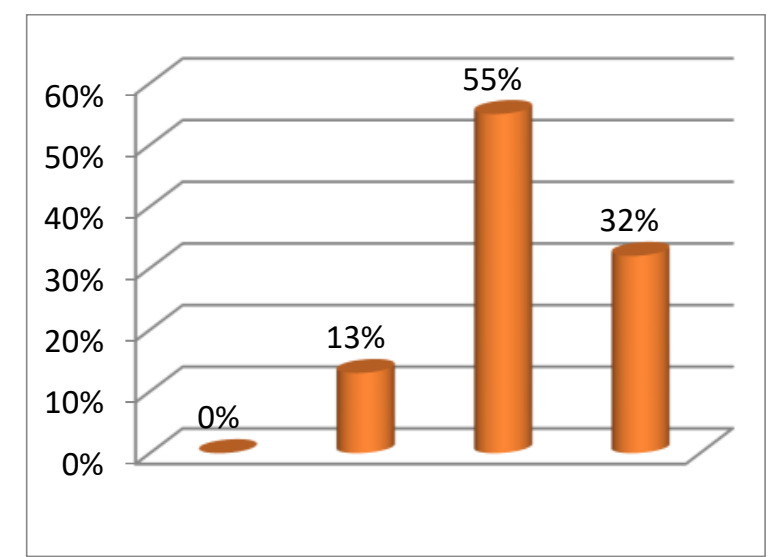

Fig.8. The opinion of alumni on the job market information source activities

In Figure 9 the following is the first amount of salary received after work alumni answer getting the first salary of over one million, there are $53.3 \%$, then $40 \%$ say they get the first salary between Rp. 600,000-Rp. 1,000,000, and only 6.7\%, whose first salary is less than Rp. 600,000 . 


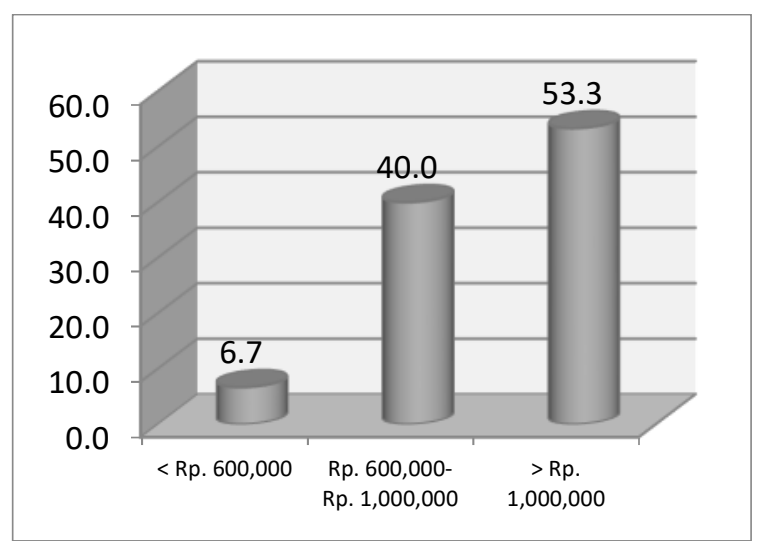

Fig.9. Obtaining the First Salary of Alumni

Next to the question where the agency works, alumni answered that only $2 \%$ said they worked for government agencies. The rest works for private institutions (98\%).

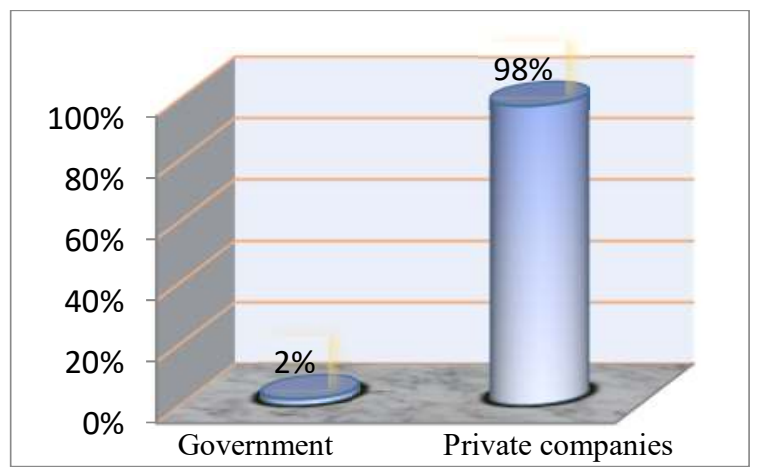

Fig. 10. Institutions where Alumni work

Alumni Assessment of Organizing and Quality of Service Alumni assessment of service delivery and quality in the Cosmetology Education study program is seen from the alumni's perceptions of aspects: 1) administrative services, 2) aspects of learning, 3) study program facilities, and 4) learning experience. On aspects of administrative services that include service effectiveness, speed of file settlement, officer communication skills, and friendliness in service are good. In the aspect of the learning process which includes lecturer and student interaction, the learning process in the classroom, practicum and research writing are good. This is shown by the acquisition of quality achievement values of $69 \%$.

Some alumni feel that the study program has provided convenience in administrative services and teaching and learning processes. In the learning aspect the acquisition of achievement scores of $69 \%$ alumni satisfaction perceptions in the good category, of course, would be better if improved. Whereas in the aspect of study program facilities alumni satisfaction scores reached $73 \%$. Respondents felt that service quality was sufficient but needed an increase in terms of Human Resources (HR) and facilities and infrastructure so that quality could compete with other universities and the output of students could compete in the world. On the aspect of alumni's assessment of learning experiences outside, the achievement score of satisfaction perception quality was $72 \%$. This shows that alumni learning experiences 
obtained from activities during the study such as internships / industrial practices, industry visits, and student organizations activities are able to equip alumni in the workforce. Alumni also provide input to further improve career development and guidance, including through collaboration or building partnerships from other companies to start recruiting graduates of Cosmetology Education Study Programs so that graduates will find it easier to find work, not only as teachers but also as private employees in the company which can involve alumni who have been directly involved in the Business World and the Industrial World. The alumni's assessment of the implementation and quality of services in the Cosmetology Education study program as a whole can be seen in the following table:

Table 1. Table of Alumni Assessment of Quality of Study Program Services

\begin{tabular}{lcc}
\multicolumn{1}{c}{ Aspect } & Percentage & Categories \\
\hline Administrative Services & $69 \%$ & Good \\
Learning & $69 \%$ & Good \\
Facilities in the Study Program & $73 \%$ & Good \\
Learning experience & $72 \%$ & Good \\
\hline
\end{tabular}

Alumni User Appraisal of Graduates Competence User perceptions of the alumni competency in Cosmetology Education Study Program aside from the school and company respondents where alumni work. Aspects assessed include: 1) integrity, 2) professionalism, 3) use of language, 4) use of makeup electronics, 5) communication, 6) teamwork, and 7) selfdevelopment On aspects of workability, alumni users at school feel that the level of integrity, professionalism, communication, teamwork and self-development is very good. This shows that the alumni of the Cosmetology Education Study Program can apply the competencies obtained during the lecture and place the position where the alumni work.

Based on the perceptions of respondents in the company obtained a little deficiency that is expected to be an input for the Cosmetology Education Study Program, namely the use of language, especially English in the company still needs to be improved. Respondents also added that the alumni of the Cosmetology Education Study Program already had good morale and competence, but needed to improve their ability in speaking English because companies in the field of Cosmetology were very closely related to the international community. In addition, cooperation with other colleagues also needs to be improved. This is needed so that teams can transfer mutual knowledge.

Based on the general description it can be stated that graduates who were made respondents had relatively homogeneous conditions and characteristics, both from their gender, age and origin of their area. Whereas based on the number of graduates used as respondents, they showed a tendency toward increasing in their force when they entered as students. This fact is caused by the difficulty of obtaining communication with earlier graduate students (tracking respondents is easier for alumni who graduate later).

The lecture material reflected in the curriculum of the Cosmetology Education Study Program, according to the alumni, is still relevant to the demands of their field of expertise in employment, so it is well stated to support the field / material in the school. This proves that alumni have sufficient knowledge and skills that are synergized with the development of the curriculum in schools or other educational fields. Nevertheless the Education Planning Education program accommodates input in the form of suggestions from alumni related to the learning system and curriculum developed. Suggestions such as those that have been disclosed are certainly very useful for study programs to be recommended in curriculum development. Because the curriculum must always be developed so that it can fit and synergize with the demands of users and demands for the development of time (science and technology). 


\section{Conclusion}

The conclusion of this tracer study activity is the collection of alumni data in the Cosmetology Education Study Program, where it is located, the absorption of graduates by the "market" (waiting period to get a job), first salary earned, employment, curriculum relevance with work, employment status and alumni response about the importance of mastering competencies: English, Computers, soft skills and entrepreneurship.

\section{References}

[1] Cabrera, A.F., de Vries, W. and Anderson, S. (2008) 'Job Satisfaction Among Mexican Alumni: a Case of Incongruence Between Hunch-Based Policies and Labor Market Demands', Higher Education, 56(6), pp. 699-722.

[2] Abu Ahmadi dan Widodo Supriyono, 2004. Psikologi Belajar. Jakarta: PT. Rineka Cipta.

[3] Ahamad Rifa'i dan Chatharina Tri Anni. 2009. Psikologi Pendidikan. Semarang: Unnes Press.

[4] Dobbins, B. W., \& Berge, Z. L. (2006). Support for distance education and training. Distance Learning (USDLA), Vol. 3, Issue 1. Galusha, J. M. (2008). Barriers to learning in distance education. Retrieved July 22, 2008. Diakses di: http://168.144.129.112/Articles/Barriers/Learning/Distance/Education.rtf pada tanggal 27 Maret 2018

[5] Hake, R.R. 1998. Interactive-Engagement vs Traditional Methods. Am.J. Phys, 66 (1): 64-67.

[6] I Gusti Bagus M. D., 2012. Pengaruh Penggunaan Job Sheet Terhadap Prestasi Belajar Peserta Didik Pada Mata Diklat Praktik Las DasarDi SMK Negeri 2 Klaten. Skripsi. Yogyakarta: Universitas Negeri Yogya.

[7] Made Wena. 2012. Strategi Pembelajaran Inovatif Kontemporer. Jakarta: Bumi Aksara

[8] Martinis Yamin, 2008. Desain Pembelajaran Berbasis Tingkat Satuan Pendidikan. Jakarta: Gaung Persada Press Jakarta

[9] Muhibin Syah. 2003. Psikologi Belajar. Jakarta: PT. Raja Grafindo Persada

[10] Sugiyono. 2010. Metode Penelitian Pendidikan Pendidikan. Bandung : Alfabeta

[11] Suharsimi Arikunto. 2010. Prosedur Penelitian Pendidikan Suatu pendekatan Praktik. Jakarta: Rineka Cipta 